\title{
Lauriomyces acerosus: a new record for the Americas
}

\author{
Priscila Silva Miranda ${ }^{\natural}$, Thaiana Santos Oliveiraa®, Edna Dora Martins Newman Luz ${ }^{\mathrm{b}}$, \\ José Luiz Bezerra阷
}

\begin{abstract}
a Programa de Pós-Graduação em Produção Vegetal, Universidade Estadual de Santa Cruz, Ilhéus, 45662-900, Bahia, Brasil.
b Comissão Executiva do Plano da Lavoura Cacaueira, Ilhéus, 45600-970, Bahia, Brasil.
\end{abstract}

Received: June 25, 2020 / Accepted: September 23, 2020 / Published online: January 27, 2021

\begin{abstract}
The genus Lauriomyces is characterized by solitary or synnematous pigmented conidiophores containing acropetal chains of unicellular and hyaline conidia formed in an adherent head. The aim of the present study was to report a new record of Lauriomyces acerosus growing on the litter of Lafoensia pacari in southern Bahia, Brazil. The collections were carried out from October 2018 to July 2019. Twenty fallen leaves were collected in different stages of decomposition. The leaf samples were carefully washed in running water and incubated in humid chambers. The structures of the fungus were assembled in PVLG resin and observed under a light microscope. The identification was carried out by specific bibliographies. And based on morphology, it was possible to identify the fungus as L. acerosus, a new report of this species for the American continents
\end{abstract}

Keywords: Biodiversity, Lafoensia pacari, litter, taxonomy.

\section{Lauriomyces acerosus: novo registro para as Américas}

\begin{abstract}
Resumo
O gênero Lauriomyces é caracterizado por conidióforos pigmentados solitários ou sinnematosos contendo cadeias acropetais de conídios unicelulares e hialinos formados em uma cabeça aderente. O objetivo do presente estudo foi relatar um novo registro de Lauriomyces acerosus crescendo na serapilheira de Lafoensia pacari no sul da Bahia, Brasil. As coletas foram realizadas no período de outubro de 2018 a julho de 2019. Foram coletadas 20 folhas caídas em diferentes estágios de decomposição. As amostras de folhas foram cuidadosamente lavadas em água corrente e incubadas em câmaras úmidas. As estruturas do fungo foram montadas em resina PVLG e observadas ao microscópio de luz. A identificação foi realizada por bibliografias específicas. E com base na morfologia, foi possível identificar o fungo como L. acerosus, um novo relato dessa espécie para os continentes americanos.
\end{abstract}

Palavras-chave: Biodiversidade, Lafoensia pacari, serapilheira, taxonomia.

The genus Lauriomyces was introduced by Castañeda-Ruíz \& Kendrick (1990) with the type species Lauriomyces pulcher RF Castañeda and WB Kendr and characterized by solitary (or synnematous), pigmented conidiophores bearing acropetal chains of unicellular and hyaline conidia (Castañeda-Ruiz \& Kendrick, 1990). According to Castañeda-Ruiz \& Kendrick (1990), Haplographium Berk. \& Br. and Lauriomyces RF Castañeda showed no difference in same type of conidiogenesis and a coloration between the base and the conidiophore apex. However, Lauriomyces was distinguished from Haplographium by the persistent chains of conidia and conidia of Haplographium are aggregated in mucilage (Castañeda-Ruiz \& Kendrick, 1990). Currently, twelve accepted taxa for Lauriomyces (i.e. $L$. acerosus, $L$. basitruncatus, L. bellulus, L. catenatus, L. cylindricus, L.ellipticus, L. glumateus, L. heliocephalus, L. pulcher, L.sakaeratensis, L. synnematicus and $L$. ventricosus) have been described and listed in an on-line database to index all scientific names in MycoBank and Index Fungorum (Index Fungorum, 2019; http://www.indexfungorum.org/Names/ Names.asp; Crous et al., 2004; http://www.mycobank.org). The fungi are mainly distinguished by the shape and size of the conidia (Castañeda \& Kendrick, 1990), which are aseptate, smooth, clavate or obclavate to fusiform, cylindrical or ellipsoid.

Lauriomyces species are cosmopolitan fungi occurring on different continents of both hemispheres. For example, $L$. bellulus was previosly reported in Switzerland (Crous \& Wingfield, 1994) and Japan (Ohnuki et al., 2009). In the Americas, L. heliocephalus was found in Brazil (Piccolo \& Silva, 1996). In addition, Thai new species (L. sakaeratensis, L. cylindricus, L. ellipticus, L. glumateus, L. basitruncatus, ) have been described in the Kingdom of Thailand (Somrithipol, Kosol \& Gareth-Jones, 2006; Somrithipol \& Jones, 2007; Somrithipol et al., 2017). 
Lafoensia pacari A. St. Hil., is a species of plant in the family Lythraceae (Order Myrtales and found in the Atlantic Forest of southern Bahia, Brazil (CNCFlora, 2020). Based on the IUCN Red List of Threatened Species, the plant is also classified as "Least Concern" (REDLIST, 2020; iucnredlist.org/species/35582/9936410). The aim of present study was to report a new record of $L$. acerosus growing on the litter of $L$. pacari in southern Bahia, Brazil. Illustrations and line drawings of microstructures are presented.

Fungal specimens collected at the Cocoa Research Center CEPEC, a department of the Executive Committee of the Cacao Plantation Plan - CEPLAC, of the Ministry of Agriculture, Livestock and Supply - MAPA. The area is located at km 22 of Jorge Amado highway, in the municipality of Ilhéus- Bahia, Southern Bahia, Brazil.

The collections were carried out during a period in October 2018 to July 2019 in a delimited area of $200 \mathrm{~m}^{2}$. Twenty fallen leaves in different decomposition stages were randomly collected. The samples were placed in Kraft paper bags and transported to the Fungal Biodiversity Laboratory of the CEPEC-CEPLAC, Ilhéus-Bahia in Brazil (Latitude: 14 ${ }^{\circ} 47^{\prime}$ $20^{\prime \prime} \mathrm{S}$ and Longitude: $39^{\circ} 02^{\prime} 58^{\prime \prime} \mathrm{W}$ ).

The samples were immediately placed in improvised sieves, transferred in plastic containers, gently washed in running water for one hour to remove impurities. Then, the samples were placed in plastic boxes lined with soaked foams and opened daily for air renewal for fifteen minutes, following the techniques described in Castañeda-Ruiz, Gusmão, HerediaAbarca e Saikawa (2006). After 48 hs, the incubated material was daily observed under a binocular scope (Motic SMS-168) for 30 days. Any fungi found on the leaves were transferred by using a thin needle to be mounted between slides and coverslip in a permanent mounting medium (PVLG resin: polyvinyl alcohol + lactoglycerol) (Morton, Bentivenga \& Wheeler, 1993). Morphological characterization was observed and described at light microscope (Leica DM 500) and identification by the specific bibliographies i.e. (Somrithipol, Kosol \& Gareth-Jones, 2006; Somrithipol \& Jones, 2007; Somrithipol et al., 2017).

Morphologically, the fungus was identified as L. acerosus, according to the description provided by Somrithipol et al. (2017). It was first described on a dead leaf from Nakhon Rashasima Province, Thailand with 13 May 2008, C. Chamoi, CC0030 in BBH and BCC33373 as the collected date, the collector, the herbarium code, and the ex-type living culture code, respectively.

\section{Description based on the Brazilian material:}

Lauriomyces acerosus Somrithipol, Suetrong \& E.B.G. Jones, Cryptog. Mycol. 38 (2): 265 (2017) (Fig. 1a-b).

Mycelium immersed. Stroma and hyphopodia missing. Setae absent. Conidiophores macronematous and mononematous, $50-80 \mu \mathrm{m}$ long, $3-4 \mu \mathrm{m}$ wide, showing primary cylindrical, thin-walled, smooth hyaline branches. Ramoconidia and conidia holoblastic, schizolytic, unicellular, hyaline, smooth-walled forming acropetal chains. Conidia not septate, elongated, cylindrical conidia with subacute extremities, tapered, 4-5 $\mu \mathrm{m}$ long and 1.0-1.2 $\mu \mathrm{m}$ wide. Sexual morph: not observed.
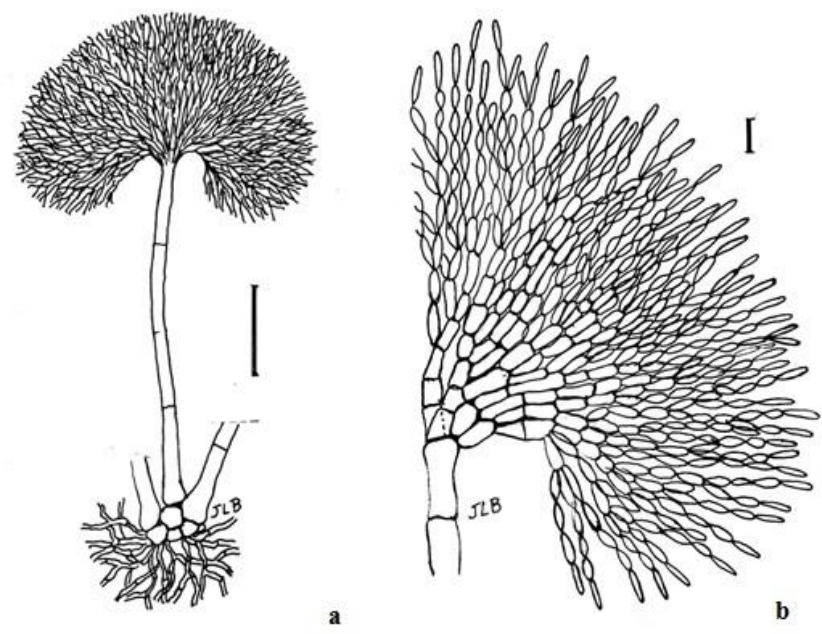

Figure 1. Lauriomyces acerosus. a: Schematic drawing of conidiophores and mycelium; b: Schematic detail of a conidial head showing ramoconidia and conidia. Bars: $\mathrm{a}=40$ $\mu \mathrm{m} ; \mathrm{b}=4 \mu \mathrm{m}$. (P.S.Miranda 8).

Geographic distribution: Thailand (2017) and Brazil (in this paper).

Material examined: BRAZIL. Bahia: City of Ilhéus, CEPLAC, on decaying leaves of Lafoensia pacari (S $14^{\circ} 45$ '26 ", W $39^{\circ} 14^{\prime} 23$ "; S $14^{\circ} 45^{\prime} 25$ ", W 39॰ 14' 23"), 26.X.2018, P.S.Miranda (CEPEC2524); 03.XII.2019, P.S.Miranda (CEPEC2525).

The Brazilian material fits well with the characteristics of L. acerosus, although it presents slightly smaller conidiophores $(50-80 \times 3-4 \mu \mathrm{m})$ than those of the original description (up to $110 \times 4-5 \mu \mathrm{m}$ ) (Somrithipol et al., 2017). Lauriomyces acerosus differs morphologically from other Lauriomyces species by its cylindrical conidia with subacute extremities, and differs from the species registered in Brazil: Lauriomyces heliocephalus has somewhat truncated or slightly rounded conidia at both ends; and $L$. sakaeratensis has truncated conidia. Lauriomyces heliocephalus was originally described by R.F. Castañeda \& Kendr (1990) in Cuba, on Alchornea latifolia leaf. In Brazil, this species was reported in the state of São Paulo by Piccolo \& Silva (1996) in leaves of Alchornea triplinervia litter and later in Bahia (Gusmão \& Maia, 2006), Piauí (Silva, Santa Izabel \& Gusmão, 2014), Ceará (Santa Izabel \& Gusmão, 2018) and Amapá (Monteiro, Sarmento \& Sotão, 2019). Lauriomyces sakaeratensis described by Somrithipol, Kosol \& Jones (2006) on fallen leaves of Dipterocarpus costatus in Thailand was first reported in Brazil (state of Bahia) on leaves and petioles submerged by Barbosa \& Gusmão (2011), and on Cedrela odorata litter (state of Pará) (Santos, Sotão, Monteiro, Gusmão \& Gutiérrez, 2018).

Due to not obtaining culture of our fungus, a DNA characterization was not possible.

Morphologically, we report Lauriomyces acerosus for the first time for the Brazilian mycota and for the Americas (the totality of the continents of North and South America). 


\section{Acknowledgements}

This work was funded by Capes under granting the scholarship to the first (88882.451313/2019-01) and second (88882.451314/2019-01) authors. A research grant from the Conselho Nacional de Pesquisas - CNPq (309340/2017-9) to the last author is also acknowledged. We are also grateful to the Executive Committee of the Cacao Crop Plan (CEPLAC) for providing the Laboratory to conduct the fungal research. The authors are indebted to the handling editor and the anonymous reviewers for critical reading the manuscript.

\section{References}

Barbosa FR, \& Gusmão, LFP. (2011) Conidial fungi from semi-arid Caatinga Biome of Brazil. Rare freshwater hyphomycetes and other new records. Mycosphere, 2(4), 475-485.

Castaneda-Ruiz, R.F \& Kendric, B. (1990) Conidial fungi from Cuba: I. Univ. Waterloo Biol. Ser. 32, 1-53.

Castañeda-Ruiz, R.F., Gusmão, L.F.P., Heredia-Abarca, G. \& Saikawa, M. (2006) Some hyphomycetes from Brazil. Two new species of Brachydesmiella, two new combinations for Repetophragma and new records. Mycotaxon, 95, 261-270.

CNCFlora. Lafoensia pacari. Available in: http://cncflora.jbrj.gov.br/portal/ptbr/profile/Lafoensia pacari.

Crous, P.W. \& Wingfield, M.J. (1994) Sporendocladia fumosa and Lauriomyces bellulus sp.nov. from Castanea cupules in Switzerland. Sydowia, 46, 193-203.

Crous, P.W., Gams,W., Stalpers, J.A., Robert, V. \& Stegehuis, G. (2004) MycoBank: an online initiative to launch mycology into the 21st century. Studies in Mycology, 50, 19-22.

Gusmão, L.F.P. \& Maia, L.C. (2006) Diversidade e caracterização dos fungos do semi-árido brasileiro, 2, 219.

Index fungorum, Cabi Bioscience Databases (2019) Available in: http://www.indexfungorum.org/NAMES/Names.asp.

Monteiro, J.S., Sarmento, P.S.M. \& Sotao, H.M.P. (2019) Saprobic conidial fungi associated with palm leaf litter in eastern Amazon, Brazil. An. Acad. Bras. Ciênc., Rio de Janeiro, 91(3). 1-19. doi: 10.1590/00013675201920180545

Morton JB, Bentivenga SP \& Wheeler WW (1993) Germplasm in the International Collection of Arbuscular and Vesicular-Arbuscular Mycorrhizal Fungi (INVAM) and procedures for culture development, documentation and storage. Mycotaxon, 48, 491- 528.

Ohnuki T, Yano T, Ono Y, Kozuma S, Suzuki T, Ogawa Y \& Takatsu T (2009) Haplofungins, novel inositol phosphorylceramide synthase inhibitors, from Lauriomyces bellulus SANK 26899 I. Taxonomy, fermentation, isolation and biological activities. Journal of Antibiotics, 62, 545-549. doi: 10.1038/ja.2009.72

Piccolo Grandi, RA \& Silva Attili, D (1996) Hyphomycetes on Alchornea triplinervia (Spreng.) Muell. Arg. leaf litter from the ecological reserve Jureiaitatins, State of Sao Paulo, Brazil. Mycotaxon, 60, 373-386.

REDLIST. Lafoensia pacari (2020) Available in: iucnredlist.org/species/35582/9936410.

Santa Izabel TS \& Gusmão LFP (2018) Richness and diversity of conidial fungi associated with plant debris in three enclaves of Atlantic Forest in the Caatinga biome of Brazil. Plant Ecology and Evolution, 151(1) 35-47. doi: 10.5091/plecevo.2018.1332

Santos RF, Sotão HMP, Monteiro JS, Gusmão LFP, Gutiérrez AH (2018) Conidial fungi associated with leaf litter of red cedar (Cedrela odorata) in Belém, Pará (eastern Brazilian Amazon). Acta Amaz., Manaus, 48(3), 230-238. doi: 10.1590/1809-4392201704411

Silva SS, Santa Izabel TS \& Gusmão, LFP (2014) Fungos conidiais e substratos vegetais submersos em algumas áreas do bioma Caatinga. Rodriguésia, 65(2), 527-538. doi: 10.1590/S2175-78602014000200014

Somrithipol S, Kosol S \& Jones EBG (2006) Lauriomyces sakaeratensis sp. nov., a new hyphomycete on decaying Dipterocarpus costatus fruits from Sakaerat Biosphere Reserve, Thailand. Nova Hedwigia, 82, 209-215. doi: 10.1127/0029-5035/2006/0082-0209
Somrithipol S \& Jones EBG (2007) Lauriomyces cylindricus and Lauriomyces ellipticus spp. nov., two new hyphomycetes from tropical forest of Thailand. Nova Hedwigia ,84, 479-486. doi: 10.1127/00295035/2007/0084-0479

Somrithipol S, Gareth Jones EB, Bahkal AH, Suetrong S, Sommai S, Chamoi C, Johnston PP, Cooper JJ \& Rungjindamai N (2017) Lauriomyces, a new lineage in the Leotiomycetes with three new species. Cryptogamie, Mycologie, 38(2) 259-273. doi: 10.7872/crym/v38.iss2.2017.259.

\section{License: Creative Commons CC BY 4.0}

This article was published with open access for distribution under the terms of the Creative Commons Attribution License, which allows unrestricted use, distribution, and reproduction in any medium, provided the original work is properly cited. 